\title{
Evaluation of Different Sulphur Sources on Sunflower (Helianthus Annuus L.)
}

\author{
G. S. Vala, J. J. Vaghani, andV. N. Gohil \\ Agricultural Research Station (Fruit Crops), Junagadh Agricultural University, \\ Mahuva-364290. Dist-Bhavnagar (Gujarat)
}

\begin{abstract}
Sunflower is an important edible oilseed crop of the country and its oil is consider as premium because of its high poly unsaturated fatty acid content with high level of lenoleic acid and absence of linolenic acid. A field trial was conducted at the Agricultural Research Station, Junagadh Agricultural University, Amreli to study the "Evaluation of different sulphur sources on sunflower". The experimental was laidout inRandomized Block Design with four replications. There were 9 treatments comprising. The analysis of three year pooled data revealed that the treatment $T_{8} 40 \mathrm{~kg}$ sulphur/ ha through gypsum $(266 \mathrm{~kg} / \mathrm{ha})$ in soil addition with recommended dose of chemical fertilizer get higher oil content and higher yield of sunflower with higher BCR value.
\end{abstract}

Keywords: Sunflower, Sulphur, Gypsum

\section{Introduction:}

Sunflower is a potential remunerative oil seed crop of the world due to its desirableattributes such as early maturity, adaptability to a wide range of climate and soil, photo-thermoinsensitiveness, drought tolerance and responsiveness to better productionmanagement practices Sunflower is an important edible oilseed crop of the country and its oil is consider as premium because of its high poly unsaturated fatty acid content with high level of linoleic acid and absence of linolenic acid. Besides nitrogen and phosphorus, sulphur also play an important role for enhancing the seed and oil yield of sunflower. The requirement of sulphur and cheap source of sulphur for higher seed and oil yield.

Apart from climatic conditions, nutrients available for growth and development may influence the overall plant structure and yield. Sulphur is the fourth major nutrient in crop production. Most of the crops require as much sulphur as phosphorus. Sulphur is the component of the aminoacids, cystin, cystein and methionine, needed for chlorophyll (Marschner, 1995). Sulphur also plays animportant role in the chemical composition of seeds. Itincreases the percentage of oil (Saron\&Giri, 1990). Poonia(2000) recorded significant increase in dry matter, plantheight, head diameter, number and weight of seeds, testweight, seed and biological yields of sunflower whensulphur was applied at $25 \mathrm{~kg} \mathrm{~S}$ ha-1. The increase in seedyield was observed up to 50 kg S ha-1. Similarly, Wani et al.(2001) observed significant increase in seed yield andprotein content of sunflower with the increase in sulphurlevel. Sulphur takes time to become available to plants, thusaffects the succeeding crop. Babu and Hegde (2002) studiedthe residual response of sulphur on rice-sunflower andsunflower-groundnut cropping systems. The residual effecton succeeding sunflower crop resulted in 37\% increase inseed yield and $45 \%$ increase in oil yield.Though sunflower is a temperate zone crop, it canperform well under various climatic and soil conditions. Thewider adaptability of the crop and wide range of climatic condition.

\section{Material And Methods:}

The experiment was conducted at Agricultural Research Station, Junagadh Agricultural University, Amreli. The soil of the experiment site was medium black. The experiment was laid out in randomized block design with 9 treatments 1) Control, 2) $20 \mathrm{~kg}$ sulphur/ha through Ammonium sulphate, 3) 20kg sulphur/ha through single super phosphate, 4) $20 \mathrm{~kg}$ sulphur/ha through gypsum, 5) $20 \mathrm{~kg}$ sulphur/ha through elemental sulphur, 6) $40 \mathrm{~kg}$ sulphur/ha through Ammonium sulphate, 7) $40 \mathrm{~kg}$ sulphur/ha through single super phosphate 8) $40 \mathrm{~kg}$ sulphur/ha through gypsum 9) $40 \mathrm{~kg}$ sulphur/ha through elemental sulphur and with four replication. The plot size was $4.2 \times 5.00 \mathrm{~m}$. Well decomposed farm yard manure was applied uniformly at the rate of 10 tons per hectare at time of land preparation. Recommended doze of fertilizer applied uniformly. All other agronomic practices followed uniformly. Data on days to $50 \%$ flowering, plant height, head diameter, plant stand, yield per plant in gram, 100 seed weight, $100 \mathrm{ml}$ wt. in gram seed filling oil per cent and plant height were recorded. Yield was also computed on the basis hectare. The data were analyzed statistically. Economics was also worked out in terms of gross and net realization on the basis of the prevailing market rate. 
Table:1 Physico- chemical properties of soil soil up to $15 \mathrm{~cm}$ depth

\begin{tabular}{cccc}
\hline Physical properties & & Chemical properties & \\
Sand & $30.51 \%$ & $\mathrm{pH}$ & 7.78 \\
Silt & $22.41 \%$ & EC mmhos $/ \mathrm{cm}$ & 0.24 \\
Clay & $47.08 \%$ & Available Nitrogen & $180.00 \mathrm{~kg} / \mathrm{ha}$ \\
& & Available Phosphorus & $20.50 \mathrm{~kg} / \mathrm{ha}$ \\
& & Available Potash & $388.50 \mathrm{~kg} / \mathrm{ha}$ \\
\hline
\end{tabular}

\section{Effect of sulfur on seed yield}

\section{Results And Discussion}

The seed yield data presented in Table :-2, Pooled analysis of three years results indicated that the response of various sulphur treatments on seed yield of sunflower found significat during 2006, 2007 and 2008. During kharif 2006, treatment $\mathrm{T}_{8}$ (40 kg sulphur/ha through gypsum recorded the maximum seed yield of 915 $\mathrm{kh} / \mathrm{ha}$ and at par with by treatments $\mathrm{T}_{7}(870 \mathrm{~kg} / \mathrm{ha}), \mathrm{T}_{9}(849 \mathrm{~kg} / \mathrm{ha}), \mathrm{T}_{4}(878 \mathrm{~kg} / \mathrm{ha}), \mathrm{T}_{6}(804 \mathrm{~kg} / \mathrm{ha})$.

In the year of 2007, treatment $\mathrm{T}_{8}$ gave the maximum seed yield of $1248 \mathrm{~kg} / \mathrm{ha}$ but was at par with treatments $\mathrm{T}_{9}(1141 \mathrm{~kg} / \mathrm{ha}), \mathrm{T}_{7}(1123 \mathrm{~kg} / \mathrm{ha}), \mathrm{T}_{6}(1066 \mathrm{~kg} / \mathrm{ha})$ and $\mathrm{T}_{5}(14050 \mathrm{~kg} / \mathrm{ha})$ respectively

During kharif -2008 , maximum seed yield of $1172 \mathrm{~kg} / \mathrm{ha}$ in treatment $\mathrm{T}_{8}$ was observed, however, it was at par with $\mathrm{T}_{9}(1061 \mathrm{~kg} / \mathrm{ha}), \mathrm{T}_{7}(1054 \mathrm{~kg} / \mathrm{ha})$ and $\mathrm{T}_{5}(976 \mathrm{~kg} / \mathrm{ha})$.

Pooled analysis revealed that the maximum sunflower seed yield of $1077 \mathrm{~kg} / \mathrm{ha}$ was recorded under treatment $\mathrm{T}_{8}$ ( $40 \mathrm{~kg}$ sulphur/ha through gypsum), it was at par with treatment $\mathrm{T}_{9}(985 \mathrm{~kg} / \mathrm{ha}), \mathrm{T}_{7}(983 \mathrm{~kg} / \mathrm{ha}) \mathrm{T}_{6}$ $(931$

Table: 1 Effect of different treatments on seed yield of sunflower

\begin{tabular}{|l|l|l|l|l|}
\hline \multirow{2}{*}{ Treatments } & \multicolumn{3}{|c|}{ Seed yield kg/ha } & \multirow{2}{*}{ Pooled } \\
\cline { 2 - 4 } & $\mathbf{2 0 0 6}$ & $\mathbf{2 0 0 7}$ & $\mathbf{2 0 0 8}$ & \\
\hline $\mathbf{T}_{\mathbf{1}}$ & 649 & 715 & 652 & 647 \\
\hline $\mathbf{T}_{\mathbf{2}}$ & 775 & 926 & 848 & 820 \\
\hline $\mathbf{T}_{\mathbf{3}}$ & 759 & 937 & 860 & 823 \\
\hline $\mathbf{T}_{\mathbf{4}}$ & 878 & 984 & 913 & 892 \\
\hline $\mathbf{T}_{\mathbf{5}}$ & 810 & 1050 & 976 & 915 \\
\hline $\mathbf{T}_{\mathbf{6}}$ & 804 & 1066 & 1014 & 931 \\
\hline $\mathbf{T}_{\mathbf{7}}$ & 870 & 1123 & 1054 & 983 \\
\hline $\mathbf{T}_{\mathbf{8}}$ & 915 & 1248 & 1172 & 1077 \\
\hline $\mathbf{T}_{\mathbf{9}} \mathbf{S E m +}$ & 849 & 1141 & 1061 & 985 \\
\hline C.D.at 5 \% & 134.84 & 80.25 & 69.37 & 61.78 \\
\hline C.V.\% & 9.56 & 240.60 & 207.97 & 185.22 \\
\hline YxT & SEm+ & 12.06 & 12.65 & 11.42 \\
\hline & & $\mathbf{6 5 . 2 5}$ & C.D.at 5\% & NS \\
\hline
\end{tabular}

\section{EFFECT OF DIFFERENT TREATMENTS ON OIL YIELD AND SEED YIELD OF SUNFLOWER}
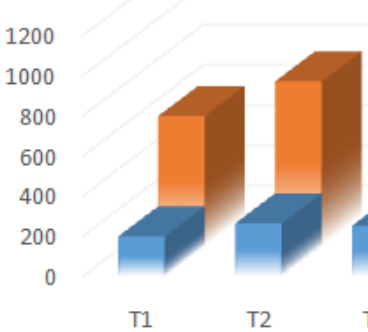

T3

T4

T5

T6

7

T9

moil yield kg/ha m Seed yield kg/ha 
Table: 2 Economics influence by different sulphur treatments on seed yield of sunflower

\begin{tabular}{|c|l|l|l|l|l|l|}
\hline Treatments & $\begin{array}{l}\text { Seed yield } \\
\text { kg/ha }\end{array}$ & $\begin{array}{l}\text { Oil yield } \\
\text { kg/ha }\end{array}$ & $\begin{array}{l}\text { Gross } \\
\text { income } \\
\text { Rs/ha }\end{array}$ & $\begin{array}{l}\text { Cost of culti. } \\
\text { Rs/ha }\end{array}$ & $\begin{array}{l}\text { Net return } \\
\text { Rs/ha }\end{array}$ & BCR \\
\hline T1 & 647 & 197.34 & 16826 & 7960 & 8866 & 1.11 \\
\hline T2 & 820 & 262.40 & 21333 & 8751 & 12582 & 1.44 \\
\hline T3 & 823 & 251.02 & 21405 & 8810 & 12595 & 1.43 \\
\hline T4 & 892 & 292.58 & 23182 & 8950 & 14232 & 1.59 \\
\hline T5 & 915 & 299.21 & 23779 & 8970 & 14809 & 1.65 \\
\hline T6 & 931 & 319.33 & 24205 & 9542 & 14663 & 1.54 \\
\hline T8 & 983 & 328.32 & 25552 & 9660 & 15892 & 1.65 \\
\hline T9 & 1077 & 373.72 & 28000 & 9940 & 18060 & 1.82 \\
\hline
\end{tabular}

\section{Market price:}

\begin{tabular}{|c|c|c|c|}
\hline Sunflower & 26.00 Rs./kg & Ammoni. Sulphate & $6.72 \mathrm{Rs} . / \mathrm{kg}$ \\
\hline Nitrogen & $10.63 \mathrm{Rs} . / \mathrm{kg}$ & SSP & $3.40 \mathrm{Rs} . / \mathrm{kg}$ \\
\hline Elemental sulphur & $18.00 \mathrm{Rs} . / \mathrm{kg}$ & Gypsum & $0.50 \mathrm{Rs} . / \mathrm{kg}$ \\
\hline
\end{tabular}

Table:3 Effect of different treatments on yield parameters of sunflower

\begin{tabular}{|c|c|c|c|c|c|c|c|c|c|}
\hline Treatments & $\begin{array}{l}\text { Days to } \\
50 \% \\
\text { Flow. }\end{array}$ & $\begin{array}{l}\text { Days to } \\
\text { maturity }\end{array}$ & $\begin{array}{l}\text { Plant } \\
\text { height } \\
(\mathrm{cm})\end{array}$ & $\begin{array}{l}\text { Head } \\
\text { Diameter }\end{array}$ & $\begin{array}{l}\text { Yield/ } \\
\text { Plant } \\
\text { (gm) }\end{array}$ & $\begin{array}{l}100 \text { seed } \\
\text { wt. }\end{array}$ & $\begin{array}{l}100 \mathrm{ml} \\
\text { wt. (gm) }\end{array}$ & $\begin{array}{l}\text { Seed } \\
\text { filling }\end{array}$ & Oil \% \\
\hline$T_{1}$ & 58.0 & 89.5 & 119.5 & 14.5 & 11.7 & 3.7 & 32.0 & 53.0 & 30.5 \\
\hline $\mathbf{T}_{2}$ & 57.0 & 89.0 & 129.0 & 17.5 & 14.0 & 3.9 & 33.6 & 56.5 & 32.0 \\
\hline $\mathbf{T}_{3}$ & 59.5 & 91.0 & 131.0 & 18.5 & 13.7 & 3.9 & 34.3 & 60.5 & 30.5 \\
\hline $\mathbf{T}_{4}$ & 57.5 & 88.5 & 132.5 & 15.5 & 15.5 & 4.1 & 34.8 & 60.0 & 32.8 \\
\hline $\mathbf{T}_{5}$ & 59.5 & 88.5 & 131.5 & 15.0 & 15.3 & 4.2 & 34.9 & 60.5 & 32.7 \\
\hline$T_{6}$ & 56.5 & 89.5 & 129.5 & 16.5 & 15.3 & 4.1 & 35.5 & 59.5 & 34.3 \\
\hline $\mathbf{T}_{7}$ & 60.0 & 91.0 & 134.5 & 17.5 & 16.5 & 4.2 & 35.7 & 59.5 & 33.4 \\
\hline $\mathbf{T}_{8}$ & 57.5 & 87.0 & 137.0 & 19.5 & 17.6 & 4.4 & 37.0 & 62.0 & 34.7 \\
\hline $\mathbf{T}_{9}$ & 61.5 & 92.0 & 133.0 & 19.0 & 16.5 & 4.2 & 36.6 & 60.0 & 33.4 \\
\hline
\end{tabular}

\section{Discussion}

An insufficient S supply can affect yield and quality ofcrops; caused by the S involved in protein and enzymesynthesis as well it is a constituent of the amino acidsmethionine, cystin and cystein. Sulphur depletion in soil ismainly caused by leaching. It takes place when the watermoving vertical downward in soil profile is higher than thatof the water uptake of the plants, evapo-transpiration and theamount of water necessary for the saturation of the soil(Scherer, 2001). Total S requirement mainly differs betweencrop species and the development stages of plant. In generalS demand of oilseed crops are higher than those of cerealcrops as they contain more S containing compounds neededfor oil biosynthesis (Scherer, 2001). In present study, Sapplication response was positive and consistent, whichprogressively improved the yield attributes, yield and oilcontents. However, narrow range of difference may be dueto relatively lower doses of $\mathrm{S}$ used in this study. Oilseedshave high demand of $S$, 


\section{Conclusions}

Higher seed and oil yields of sunflower during the kharif season were realized withthe application of sulphur at $40 \mathrm{~kg} / \mathrm{ha}$ through gypsum $(266 \mathrm{~kg} / \mathrm{ha})$ in soil in addition to the recommended dose of chemical fertilizer. Growth and yield components were favorably influenced by S (40 kg S/ha). sulphur had beneficial effects on seed and oil yield of sunflower with higher BCR value.

\section{References}

[1]. Babu, S.N.S. and D.M. Hegde, 2002. Delineation of sulphur deficient soil and evaluation of oilseed crops responses to sulphur. FertilizerMarket. News, 33: 9-17

[2]. Marschner, H., 1995. Mineral Nutrition of Higher Plants, p: 315. AcademicPress Ltd. London

[3]. Mishra, A., P. Das and R.K. Paikaray. 1995. Yield and nutrient uptake by winter sunflower as influenced by nitrogenand phosphorus. Indian J. Agron. 40:137-138

[4]. Poonia, K.L., 2000. Effect of planting geometry, nitrogen and sulfur ongrowth and yield of sunflower (Helianthus annuus L.). J. Eco-Physiol., 3: 59-71

[5]. Saron, G. and G. Giri, 1990. Influence of nitrogen, phosphorus and sulphuron mustard under semi-arid rainfall conditions of North West India.Indian J. Agron., 35: 313-316

[6]. Sunil Kumar, R.S. Dixit and H.P. Tripathi. 1991. Effect of nitrogen on nutrient uptake and oil content of sunflower(Helianthus annuus L.) under different moisture regimes. Indian J. Agric. Sci. 61:766-768.

[7]. Tamak, J.C. H.C. Sharma and K.P. Singh. 1997. Effect of phosphorus, sulphur and boron

[8]. on seed yield and quality ofsunflower (Helianthus annuus L.). Indian J. Agron. 42:173-176.

[9]. Vedsingh, B.S. Yadav and S.R. Bhunia. 1997. Effect of planting date and irrigation management on growth and yield of spring sunflower (Helianthus annuus L.). Indian J. Agric. Sci. 67:48-50

[10]. Wani, M.A., F.A. Agha, M.A. Malik and Z.A. Rather, 2001. Response ofsunflower to sulphur application under Kashmir conditions. Appl.Biol. Res., 3: 19-22 